\title{
The Innovative Improvement through Strengthening Quality of Work Life, Situational Leadership, and Self-Efficacy by Using Scientific Identification Theory of Operation Research in Education Management (SITOREM)
}

\author{
R. Agus Sriyanta*, Didik Notosudjono, Bibin Rubini \\ PostgraduateProgram, Pakuan University, Bogor, Indonesia
}

*Corresponding Author: R. Agus Sriyanta, PostgraduateProgram, Pakuan University, Bogor, Indonesia

\begin{abstract}
The ability to beinnovative is becoming increasingly important today because the innovation process is believed to be the driving force for the development and growth of educational institutions. However, innovation does not appear without any effort from educational institutions. The purpose of this study is to find efforts to improve teacher innovativeness, namely by developing variables of work life quality, situational leadership, and self-efficacy. The method used in this study is a correlational study method to determine whether the variables in the study have a positive relationship with the innovativeness of the teacher. SITOREM analysis is used to determine priorities and recommendations for improvements that need to be made.The study population is all teachers in the Private District of Bogor Regency with the status of permanent teachers of the foundation. The sampling technique in this study used Multistage random sampling. Determination of the number of samples in the next study is to calculate the number of samples using proportional random sampling with Slovin formula to obtain 270 samples. Based on the results of quantitative research found that all variables have a significant positive relationship with teacher innovativeness. The results of the SITOREM analysis show that the components of situational leadership, teacher innovativeness, and quality of work life that require improvement are: (1) the style of delegation, (2) directing style, (3) relationships with colleagues, (4) pride \& appreciation received, (5) learning media and sources, (6) teaching materials, and (7) learning methods and evaluations. The advice that can be put forward for school principals and teachers is to maintain indicators that have good value.
\end{abstract}

Keywords: SITOREM Analysis, Teacher Innovation, Quality of Work Life, Situational Leadership, Self Efficacy.

\section{INTRODUCTION}

Innovativeness is becoming increasingly important today because the innovation process is believed to be the engine driving the development and growth of educational institutions. However, innovation does not just emerge without the efforts of educational institutions. Educational institutions must adopt proactive behavior with innovation and the creation of new business, and employees must be encouraged to behave entrepreneurially as the foundation of the innovation process. Innovation needs to be based on several preconditions so that the results of innovation have positive implications on the performance of educational institutions (Abbas et al., 2018).

The criteria for quality schools are schools which are inseparable from the quality pillars set by experts. The pillars of quality are the focus on customers, total involvement, measurement, commitment, continuous improvement. These pillars are based on school beliefs, such as selfconfidence (self-efficacy), quality of work life, achievement motivation, and leadership. Thus, leaders (principals), teachers, staff, committees, boards of education, students, parents, guardians of students, communities, and users must commit to the quality of the school.

One way to improve the quality of education is to improve the quality of teachers because teachers have a central role in the learning process in schools. The teacher is a motivator and mediator for students to be able to learn effectively and efficiently. Therefore the teacher must play a role in encouraging students to learn. In this case the teacher is required to be professional in mastering the material, carrying out learning, conducting assessments during and after learning, and always 
The Innovative Improvement through Strengthening Quality of Work Life, Situational Leadership, and Self-Efficacy by Using Scientific Identification Theory of Operation Research in Education Management (SITOREM)

following the development of science and education. This is as confirmed in Act Number 20 of 2003 concerning the National Education System stating that educators are professionals.

To be able to plan an innovative learning process that can provide useful experiences for students, teachers need to pay attention to the essential components of the learning process. From the components of the learning process, the teacher can plan activities and learning strategies that are relevant to the learning objectives.

The reality on the ground is that someone who works as a teacher does not yet have and understand innovation in the learning process, although in some schools it has made learning innovation an obligation in learning activities.

There are several possible factors related to the low innovativeness of private junior high school teachers in Bogor Regency, such as the quality of work life, principal school leadership, and selfefficacy (Rubini, et. al.2019). To observe and examine the innovativeness of the teacher, the researcher considers the independent variables such as the quality of work life, situational leadership, and self-efficacy interesting to be studied further.

Based on the background of the problem, researchers wanted to research on improving innovation through strengthening the quality of work life, situational leadership, and self-efficacy among private permanent teachers in Bogor District.

\section{LITERATURE REVIEW}

Greenberg and Baron (2008) define innovation as the act (process) of changing from something that has been formed into something new. The innovation dimensions are: (a) product innovation, including innovation of products or commodities produced / operating, (b) service innovation, including innovation about customer relationships, (c) process innovation, including methods, procedures or techniques for product procurement / services, (d) marketing innovation, including innovation in promotion and sales activities, (e) business innovation, including business development or expansion activities, and (f) organizational innovation, including innovation in governance and management.

Robbins (2013) states that "innovation is a new idea applied to initiate or to improve products, processes, and services. The innovation dimensions are: (a) Product innovation, from small improvement to change the product; (b) Process innovation, such as introducing new ideas of doing the jobs; (c) Services innovation, concerning all activities to improve the customer relations and satisfaction.

Griffin and Gregory (2014) explain that innovation is the process of creating and doing new things that are introduced into the marketplace as products, processes, or services with the following dimensions:

- radical innovations (sometimes called disruptive innovation is a significant breakthrough that changes from creating whole industries);

- System innovation creates a new functionality by assembling parts in new ways;

- Incremental innovation continues technical improvement and extends the applications of radicals and system innovations.

Krietner (2009) argues that innovation is the time it takes from new ideas to be translated into satisfied demand with the dimensions:

- Innovation process: the systematic development and practical application of a new idea b. Product technology: the second stage of the innovation process, involving the creation of a working prototype; c. Production technology: the third stage of the innovation process, involving the development of a profitable production process.

- Tidd and Bessant (2014) define that innovation is a process of turning opportunity into new ideas and of putting these into widely accepted practice with the following four dimensions:

- Production innovation: changes in things (products / services). 
The Innovative Improvement through Strengthening Quality of Work Life, Situational Leadership, and Self-Efficacy by Using Scientific Identification Theory of Operation Research in Education Management (SITOREM)

- Product innovation: changes in how they are created and delivered.

- Position innovation: changes in the context in which the product / service are introduced.

- Paradigm innovation: changes in the underlying mental models which frame what the organization does.

From some of the theories put forward above, as a general synthesis of innovation, it can be synthesized that teacher innovation is the implementation of new ideas or ideas made by the teacher in the process of teaching and learning activities that are student-centered so as to create conditions that enable students to learn optimally and can improve results maximum learning.

Islam (2012) defines the quality of work life is a concept that indicates a balance of both in personal and professional life of the individual. It is the individual's accomplishment of a satisfactory social situation within the limits of apparent physical abilities. Ahmadi et al, (2012) mention quality of work life is the feeling and perception that employees have toward their jobs, colleagues and companies Gayathiri and Ramakhrisnan (2013) explained quality of work life is the relationship between worker and environment that can be broken down into different dimensions like the social, technical and economic, in which the work is usually viewed and designed.

Cascio (2006) defines quality of work life is the employee's perception of his mental and physical well-being while working. There are two views regarding the purpose of quality of work life. First it isseveral conditions and practices of the organization, while the second, it is the perception of employees that they want security, they feel satisfied, and get the opportunity to grow and develop as human beings. Furthermore, Triatna (2015) explained quality of work life concern about the impact of work on people and organizational effectively combined with emphasis on participation in problem solving and decision making

Based on the theories stated above, it can be synthesized that quality of work Life is the feelings and perceptions of individuals about the balance of personal life and professional life in relation to work, colleagues and the organization where he works, with dimensions and indicators as follows:: 1) Dimension of personal development opportunities, with indicators: (a) professional development, (b) personal development, and community life, 2) Dimensions of freedom of initiative and action in carrying out work, with indicators : (a) implementation of the main work, and supporting work, 3) Dimensions of social life at work, with indicators: (a) pride and appreciation received, (b) relationship with colleagues, and 4) Dimension of evaluation at work, with indicators : (a) evaluation of the leadership of the performance and self-evaluation of the role of work.

Vandayaniet al. (2015) confirm situational leadership is the best way to influence people and active leadership behavior is determined by three factors that influence each other namely: task behavior, relationship behavior and follower readiness. Blanchard (2008) defines situational leadership as leaders who effectively adapt their leadership style to the level of development of the people they manage. Robbins (2013) interpret situational leadership is leadership that focuses on the readiness of followers, namely the extent to which they are willing and able to complete specific tasks. Gibson (2009) defines situational leadership as leadership that focuses on organizational activities and operational environments by emphasizing followers and their willingness to do work

Lewis et al. (2007) explain the situational leadership model is based on the interaction of certain employee characteristics, referred to as readiness, and leadership style, based on the concern for the employee. Meanwhile, Wirawan (2014) argues that situational leadership is a leadership theory based on assumptions or mindset: (1) there is no one best way to influence people, (2) effective leadership behavior is determined by the interaction of three factors, namely (a) task behavior; (b) relationship behavior; and (c) the readiness of the followers. Toha (2016) adds the notion of situational leadership is leadership based on the interrelation between the following matters: (1) the number of instructions and direction given by the leadership; (2) the amount of social support given by the leadership; and (3) the level of readiness or maturity of the followers shown in carrying out specific tasks, functions, or objectives. 
The Innovative Improvement through Strengthening Quality of Work Life, Situational Leadership, and Self-Efficacy by Using Scientific Identification Theory of Operation Research in Education Management (SITOREM)

Based on some of the above description of the theory, it can be synthesized that situational leadership is the behavior of a leader in carrying out his duties and responsibilities based on the interplay of task behavior, relationship behavior, and maturity of subordinates. The situational leadership dimensions are as follows: 1) Telling is a leader giving direction instructions about the task or order to his followers, with indicators: the style of directing to followers and the style of communication with followers, 2) Selling / Coaching is the leader giving commands in detail and clearly about tasks that must be done by his followers, with indicators: style of giving instructions to followers, 3) Participating / Supporting is the leader involving followers in the consequences of the task to increase commitment and motivation, with indicators: the style of participating with followers, 4) Delegating is the leader delegating or share responsibility for making decisions with followers, with indicators: style of giving delegates to followers.

Gibson et al., (2009) define self-efficacy is the belief that one can perform adequately in a particular situation. Ivancevich (2010) explains that self-efficacy is the belief that one can perform well in a given situation. Individuals with high levels of self-efficacy tend to display higher levels of motivation and performance, (a) Motivated to engage in the behavior that will help them perform well, (b) To learn more and transfer that learning to enhance their job performance, and, (c) Lead (his / her-self) to the higher level of goal setting and performance. Robbins (2013) defines self-efficacy also known as social cognitive theory or social learning theory) refers to individual's belief that he or she is capable of performing a task.

Hellriegel and Slocum (2011) define that self-efficacy is one's assessment of one's own ability to perform certain tasks in certain situations. Factors that influence self-efficacy are beliefs related to nature that lead to person to achieve success. The nature of trust includes integrity, humility, loyalty, self-control, courage, fairness, patience, craft, creativity, and simplicity. Bandura (2012) defines Selfefficacy is a belief in one's ability to cultivate academic knowledge and behavior and run a program of activities needed to get the desired results in certain contexts and specific tasks. Freidman and Schustack (2008) in their explanation provide an understanding that individual self-efficacy is an individual involvement such as feeling having the same or more ability than others, verbal persuasion such as advice and guidance, psychological situations such as assessing the abilities or strengths of each individual.

Kreitner and Kinicky (2013) define that self-efficacy is one's perception of how well he can function in certain situations. Self-efficacy relates to the belief that individuals can take the expected action. Result expectation is an estimation of self that the behavior carried out by the self will achieve certain results.

Based on several explanations of the theory above, it can be synthesized that self-efficacy is one's belief about his ability to do and complete tasks in accordance with their responsibilities with a certain level of success, with dimensions and indicators as follows: 1) Magnitude, is the level of task difficulty or difficulty of tasks believed to be able to overcome by employees, with indicators: (a) survive in the face of difficulties, (b) setting goals and beliefs capable of completing challenging tasks; 2) Strength, is strength or belief, with indicators: (a) confidence in the ability of the self to work well, (b) willingness to develop themselves, 3) Generality, is the degree of hope of success in various situations, with indicators: (a) optimism at work, (b) encouragement and enthusiasm at work.

Based on the above description, the following hypothesis is postulated:

- There is a positive relationship between quality of work life andteachers' innovativeness.

- There is a positive relationship between situational leadership and teachers' innovativeness.

- There is a positive relationship between self-efficacy and teachers' innovativeness.

- There is a positive relationship between quality of work life, situational leadership, and selfefficacy altogether with teachers' innovativeness.

\section{Methodology}

This research was conducted in a private junior high school in Bogor Regency, West Java Province, Indonesia. The method used in this research is the correlational study method by combining 
The Innovative Improvement through Strengthening Quality of Work Life, Situational Leadership, and Self-Efficacy by Using Scientific Identification Theory of Operation Research in Education Management (SITOREM)

SITOREM analysis. As revealed by Hardhienata (2017) for operations research in management education, we need to add the scientific identification theory mentioned above with the statistical model and step to obtain an optimal solution. Through SITOREM analysis, correlational research results are analyzed in more detail on indicators of research variables, to find indicators that need to be immediately corrected and maintained or developed.

The population of this research is all private junior high school teachers in Bogor Regency, especially those accredited with "A" status as permanent teachers of foundations (1277 teachers) spread across five districts of Bogor. The sampling technique in this study uses Multistage random sampling. Determination of the number of samples for the next study is to count the number of samples using proportional random sampling) with the Slovin formula to obtain a sample of 270.

\section{RESULTS AND DISCUSSION}

The results showed there was a positive relationship between quality of work life and teacher innovation. Based on the results of research with the hypothesis test, it is known that the correlation coefficient between teacher innovativeness (ry1) is 0.459 with the medium category. The probability value of $0,000<0.005$ then Ho is rejected, it can be concluded that the correlation coefficient is significant. Thus this study confirms that there is a significant relationship between the quality of work life and teacher innovation. The diversity of teacher innovativeness related to quality of work life is reflected in the coefficient of determination of 0.211 or $21.10 \%$ while the remaining $79.90 \%$ is influenced by other variables / factors. The results of this study get a regression equation $\hat{Y}=64.417$ $+0,519 \mathrm{X} 1$ can be used to predict teacher innovativeness based on work life quality scores, can be predicted every 1 increase in work life quality scores.

The results showed a positive relationship between situational leadership and teacher innovation. Based on the results of the research with hypothesis testing, it is known that the correlation coefficient between teacher innovativeness (ry2) is 0.486 with the medium category. The probability value of $0.000<0.005$, then Ho is rejected indicating the correlation coefficient is significant. Thus this study confirms that there is a significant relationship between situational leadership and teacher innovation. The diversity of teacher innovativeness related to situational leadership is reflected in the coefficient of determination of 0.236 or $23.60 \%$ while the remaining $76.40 \%$ is influenced by other variables / factors. The results of this study produce a regression equation $\hat{Y}=77.346+0.414 \mathrm{X} 2$ that can be used to predict teacher innovation based on situational leadership scores.

Also, the results showed a positive relationship between self-efficacy and teacher innovation. Based on the results of research with the hypothesis test, it is known that the correlation coefficient between teacher innovativeness (ry3) is 0.402 with the medium category. The probability value of 0.000 $<0.005$ then Ho is rejected denoting that the correlation coefficient is significant. Thus this study confirms that there is a significant relationship between self-efficacy and teacher innovation. The diversity of teacher innovativeness related to self-efficacy is reflected in the coefficient of determination 0.162 or $16.20 \%$ while the remaining $83.80 \%$ is influenced by other variables / factors. The results of this study generatethe regression equation $\hat{Y}=75.371+0.418 X 3$ that can be used to predict teacher innovativeness based on self-efficacy scores.

Further, the results showed a positive relationship between the quality of work life, situational leadership, and self-efficacy with teacher innovation. Based on the results of research with the hypothesis test it is known that the correlation coefficient between teacher innovativeness (ry123) is 0.573 with a moderate category. The probability value of $0.000<0.005$, then Ho is rejected showing that the correlation coefficient is significant. Thus this study confirms that there is a significant relationship between the quality of work life, situational leadership, and self-efficacy together with teacher innovation.

The contribution of the quality of work life, situational leadership, and self-efficacy are 0.327 revealing that $32.70 \%$ diversity in teacher innovation can be explained by the quality of work life, situational leadership, and self-efficacy.

The results of this study display a regression equation $\hat{Y}=35.904+0.269 \mathrm{X}_{1}+0.236 \mathrm{X}_{2}+0.215 \mathrm{X}^{3}$ used to predict teacher innovation based on scores on quality of work life, situational leadership, and 
The Innovative Improvement through Strengthening Quality of Work Life, Situational Leadership, and Self-Efficacy by Using Scientific Identification Theory of Operation Research in Education Management (SITOREM)

self-efficacy. This means that the equation can predict each increase in 1 score of situational leadership and efficacy together will increase teacher innovation by 0.269 times for the variable quality of work life, 0.236 times for the variable situational leadership and 0.215 times for the variable for self-efficacy in the constant of 35.904.

Based on the results of the SITOREM analysis it is known that the variable quality of work life with the evaluation indicators of the leadership and self-evaluation of the role of work, the implementation of primary and supporting work, personal development and social life, as well as professional development indicators have a reasonably good value can be maintained. Meanwhile, indicators of relationships with coworkers, and indicators of pride and appreciation received have a low value and efforts are needed to strengthen and improve. Activities that need to be done to improve indicators of relationships with coworkers include through programs held by schools such as family gatherings that every teacher can participate in to strengthen relationships with other coworkers. While the activities that need to be carried out to increase the indicators of pride and appreciation received among them through discussions/workshops in developing a proud attitude as a teacher who puts forward aspects of professionalism.

Based on the results of the SITOREM analysis it is known that the self-efficacy variable with indicators of encouragement and enthusiasm at work, willingness to develop themselves, optimism at work, confidence in the ability to work well, survive in the face of difficulties, and indicators of goal setting and confidence able to complete tasks that difficult to have a value that is good enough and can be maintained.

Based on the results of the SITOREM analysis it is known that the teacher's innovative variables with indicators for the preparation of work plans, teacher personality and interaction, as well as guidance and counselling, have values that are already quite good and can be maintained. Meanwhile, media indicators and learning resources, teaching materials, as well as learning methods and evaluations have low scores and efforts are needed to strengthen and improve. Activities that need to be carried out to improve media indicators and learning resources include, among others, media creation and learning resources. Professional allowance provided by the government through certification funds received by teachers is one of them to improve the quality of the teaching and learning process so that the learning outcomes achieved by students will be maximized. Activities that need to be carried out to improve indicators of teaching materials include the activities of making teaching materials / modules. Teaching materials / modules made by the teacher can be developed by each teacher according to the needs they face so that if the teacher makes teaching materials it will be more comfortable in the delivery of material in class. Activities that need to be done are improving the indicators of learning methods and evaluations including through developing methods and evaluating learning conducted by teachers. The activities of developing methods and evaluating learning conducted by teachers can contribute to improving student learning outcomes. Thus, if the teacher uses and develops media and learning resources, teaching materials, and methods and evaluation of learning in learning activities, it will increase the teacher's innovation.

Based on the results of the SITOREM analysis (Hardhienata, 2017), suggestions and recommendations can be formulated as follows: indicators which are in good condition (weight: 4-5) are recommended to be maintained. Indicators whose condition is still not right (weight: <4) are corrected.

Maintained Indicator:

- Participating Style

- Communication Style

- Instructing Style

- Evaluation from the Chairman on Performance \& Work Role Evaluation

- Implementation of Main and Support Work

- Personal Development \& Community Life

- Professional Development

International Journal of Managerial Studies and Research (IJMSR)

Page | 37 
The Innovative Improvement through Strengthening Quality of Work Life, Situational Leadership, and Self-Efficacy by Using Scientific Identification Theory of Operation Research in Education Management (SITOREM)

- Encouragement \& Excitement at Work

- Willingness to Self-Development

- Optimism at Work

- Confidence in Ability to Work Well

- Persevere in the face of difficulties

- Goal Setting and Confidence Complete the Task

- Compilation of Work Plans

- Personality and Teacher Interaction

- Counselling Guidance

Suggestions for improvement

- Delegating Style

- Directing Style

- Relationships with Colleagues

- Pride \& Awards received

- Media and Learning Resources

- Teaching Materials

- Learning Methods and Evaluation

\section{CONCLUSION}

The findings from the results of research, discussion, conclusions, and implications that have been described can be seen that the quality of work life, situational leadership, and self-efficacy can be improved. Improving teacher innovation can be done by improving the quality of work life, situational leadership, and self-efficacy of private junior high school teachers in Bogor Regency, Indonesia.

Based on the results of the SITOREM analysis, it is known that the indicators of participating styles, communication styles, and instructing styles have values that are already good enough to be maintained. Meanwhile, the indicator of delegating style and directing style has a value that is still low, and efforts to strengthen and increase are needed. Activities that need to be carried out to increase the delegation style indicators include teacher delegation activities in teacher training activities, such as seminars / workshops on education, and teacher delegation in attending official meetings so that teacher insight will increase. Meanwhile, activities that need to be carried out to improve the indicators of directing style include directing the teacher in completing the task of teaching and learning activities well, conveying the vision and mission of the school, giving direction on short-term and long-term programs. With the principal often delegating teachers in participating in professional activities and directing school principals to teachers, it will contribute to improving teacher innovation both directly and indirectly.

\section{REFERENCES}

[1] Abbas, E. W., Hadi, S., \& Rajiani, I. (2018). The prospective innovator in public university by scrutinizing particular personality traits. Polish Journal of Management Studies, 18.

[2] Ahmadi, Freyedon et.al. (2012). Survey Relationship between Quality of Work Life and Organization Commitment in Public Organization in Kurdistan Province. Interdiciplinary Journal of Contemporary Research in Business, 4.

[3] Bandura, Albert. (2012). Handbook of Principles of Organizational Behavior Indispensable Knowledge for Eviden Based Managemen Second Edition. United Kingdom: John Wiley \& Sons Ltd.

[4] Blanchard, Ken. (2008). Situational Leadership Adapt Your Style to Their Development Level. Leadership Excellence, 25, 19. 
The Innovative Improvement through Strengthening Quality of Work Life, Situational Leadership, and Self-Efficacy by Using Scientific Identification Theory of Operation Research in Education Management (SITOREM)

[5] Cascio, Wayne F. ( 2006). Managing Human Resources. Colorado: McGraw-Hill.

[6] Friedman, Howard \& W.Schustack, Miriam. 2008. Kepribadian: Teori Klasik dan Riset Modern. Edisi Ke 3. Jilid 1.Translated by : Fransiska Dian Ikarini, Maria Hany, Andreas Provita Prima. Jakarta : Erlangga.

[7] Greenberg, J. and R.A. Baron. (2008). A Behavior in Organizations. Upper Saddle River, N.J. Pearson Prentice-Hall.

[8] Gayathiri, R and Ramakhrisnan, R. (2013). Quality of Work Life-Linkage with job satisfaction and job performance. International Business and Mangement Invention, 2.

[9] Gibson, J.L. J.M. Ivancevich, J.H. Donnely, Jr. And R. Konopaske. (2009). Organizations: Behavior, Structure and Process. New York: Mc Graw-Hill.

[10] Griffin, Ricky W and Gregory Moorhead. (2014). Organizational Behavior: Managing People and Organizations, Eleventh Edition. Nelson Education Ltd: Canada-USA.

[11] Hardhienata, S. (2017). The Development of Scientific Identification Theory to Conduct Operation Research in Education Management. IOP Conf. Series: Material Science and Engineering. Vol. 166 (doi: 10.1088/1757-899X/166/1/2017).

[12] Hellriegel, Don and Jr. Jhon W. Slocum. (2011). Organizational Behavior Chapter 3. Understanding Individual Difference. South Western: Cengange Learning.

[13] Islam, Muhammad Baitul. (2012). Factors Affecting Quality of Work Life: An Analysis on Employees of Private Limited Companies in Bangladesh. Global Journal of Management and Business Research, 12, (18).

[14] Ivancevich, J.M. (2010). Human Resource Management. New York: Mc Graw-Hill.

[15] Krietner, Robert. (2009). Management Elevent Edition. Boston New York: Houghton Mifflin Hourcot Publising Company.

[16] Kreitner, Robert. Kinicki, Angelo. (2013). Perilaku Organisasi. Translated by Biro Bahasa Alkemis. Edisi 9 buku 1. Jakarta: Salemba Empat.

[17] Lewis, Pamela S., Goodman, Fandt, and Michiltsch. (2007). Management Challenges for Tommorow's Leaders. US. Thomson South-Western.

[18] Robbins, Stephen P. (2013). Organizational Behavior, $15^{\text {th }}$ edisi. USA: Prentice Hall, 2013, p. 376

[19] Rubini, B., Ardianto, D., \& Pursitasari, I. D. (2019, April). Teachers' Perception Regarding Integrated Science Learning and Science Literacy. In 3rd Asian Education Symposium (AES 2018). Atlantis Press.

[20] Tidd, Joe and Bessant, Jhon. (2014). Managing Innovation: Integrating Technological, Market and Organizational Change. United Kingdom: John Wiley \& Sons Ltd.

[21] Triatna, Cepi. (2015). Perilaku Organisasi dalam Pendidikan. PT. Remaja Rosdakarya: Bandung.

[22] Toha, Miftah. 2016. Perilaku Organisasi Konsep Dasar dan Aplikasinya. Jakarta: Rajawali Press.

[23] Vandayani, P., Kartini, D., \& Azis, Y. (2015). The impact of national culture on effectiveness of situational leadership Hersey-Blanchard. International Journal of Scientific \& Technology Research, 4(7), 78-82.

[24] Wirawan. (2014). Kepemimpinan: Teori, Psikologi, Perilaku Organisasi, Aplikasi, dan Penelitian. Jakarta: Rajawali Pers.

Citation: R. Agus Sriyanta, et.al. “ The Innovative Improvement through Strengthening Quality of Work Life, Situational Leadership, and Self-Efficacy by Using Scientific Identification Theory of Operation Research in Education Management (SITOREM)" International Journal of Managerial Studies and Research (IJMSR), vol 7, no. 12, 2019, pp. 32-39. doi: http://dx.doi.org/10.20431/2349-0349.0712005.

Copyright: (C) 2019 Authors. This is an open-access article distributed under the terms of the Creative Commons Attribution License, which permits unrestricted use, distribution, and reproduction in any medium, provided the original author and source are credited. 